\title{
Pearl Millet Utilization in Commercial Laying Hen Diets Formulated on a Total or Digestible Amino Acid Basis
}

Q Author(s)
Filardi RS*
Junqueira OM
Casartelli EM
Laurentiz AC
Duarte KF
Assuena V
Departamento de Zootecnia
Faculdade de Ciências Agrárias e Veterinárias
Campus de Jaboticabal
Universidade Estadual Paulista

\section{Mail Address}

Rosemeire da Silva Filardi

Av. Líbero Badaró, 810

Centro

14.870-540 - Jaboticabal, SP, Brazil

E-mail: rofilardi@ig.com.br

\section{Keywords}

Digestible amino acids, egg quality, laying hens, pearl millet, performance, total amino acids.

\section{Acknowledgements}

The authors thank Fundação de Amparo à Pesquisa do Estado de São Paulo (FAPESP) for financial support.

\section{ABSTRACT}

An experiment was carried out to evaluate the effect of replacing corn with pearl millet in commercial layer diets, formulated according to the minimal requirements for total and digestible amino acids. Two hundred and forty Lohmann LSL laying hens with 25 weeks of age were distributed in a completely randomized experimental design according to a $2 \times 5$ factorial arrangement with 3 replicates of 8 birds. Feed was formulated on two amino acid basis (total or digestible) according to Rostagno et al. (2000) and there were five pearl millet inclusion levels $(0 \%, 25 \%, 50 \%, 75 \%$, and 100\%). Performance and egg quality were evaluated during five periods of 21 days. At the end of each period, feed intake, egg production, egg weight and feed conversion were evaluated. In the last three days of each period, the following egg quality parameters were evaluated: Haugh Unit, yolk pigmentation index, egg specific weight, shell percentage and shell thickness. Digestible amino acid requirements resulted in decreased feed intake $(p<0.01)$ and increased production costs per mass of eggs $(\mathrm{kg})$ or per dozen eggs $(p<0.01)$ compared to total amino acid requirements. There was a linear reduction in feed intake, egg production, egg weight and yolk pigmentation index with increasing inclusion levels of pearl millet. Therefore, increasing levels of replacement of corn by pearl millet affected bird performance negatively. Besides, production costs were higher with increasing pearl millet levels.

\section{INTRODUCTION}

Some feedstuffs that are considered sources of energy and protein have been extensively studied due to their qualities as nutrient sources or the high inclusion level in diets, such as corn and soybean meal, respectively. One problem faced by poultry producers nowadays is corn availability in the market. During the period of low availability, corn price rises, which will be reflected on production costs. This problem may be attenuated if corn is totally or partially replaced by other grains, such as the pearl millet.

Pearl millet (Pennisetum americanum (L.) Leeke) is a summer annual forage with high nutritional value that might be used either for forage or grain production. According to Andrews \& Kumar (1992), pearl millet has many advantages for cultivation and grain production in semi-arid areas, mainly due to its resistance to drought and heat. Besides, pearl millet grows adequately in acid and/or sand soils with low levels of clay and organic matter. These features allow pearl millet to adapt to regions like Africa, India, Australia and Brazil, and grain production may be increased if the soil is corrected.

In terms of chemical composition, pearl millet has higher protein levels than corn and approximately $85 \%$ of the energy content of corn. 
Filardi RS, Junqueira OM, Casartelli EM, Laurentiz AC, Duarte KF, Assuena V
Pearl Millet Utilization in Commercial Laying Hen Diets Formulated on a Total or Digestible Amino Acid Basis
Considering that corn corresponds to 60 to $70 \%$ of poultry diets and accounts for $60 \%$ of all production costs, results from previous studies justify the replacement of corn by peal millet in poultry diets (Andrews \& Kumar, 1992).

Some trials have been carried out to evaluate substitution of pearl millet for corn in broiler chicken and laying hen diets. Café et al. (1999) evaluated the effect of different inclusion levels of pearl millet in substitution for corn in broiler chicken diets. There was a negative correlation between weight gain at 49 days old and pearl millet inclusion levels, so that weight gain was smaller in birds fed diets with 100\% pearl millet. The authors also observed that feed conversion and abdominal fat did not change, although leg pigmentation was poorer, suggesting that pearl millet has low carotenoid contents and a synthetic or natural source of carotene should be added to the diet in order to avoid changes in carcass pigmentation. It was concluded that levels of pearl millet higher than 50 or $75 \%$ might reduce bird final performance and the cost must be considered by broiler producers as a decisiontaking factor. A later study has also shown that the inclusion of pearl millet in broiler chicken diets at levels up to $50 \%$ resulted in performance and carcass quality similar to or better than corn-based diets (Davis et al., 2003).

In laying hen diets, although pearl millet increased egg size and n-3 fatty acid levels in egg yolk, egg production decreased and yolk color intensity was poorer (Luis et al., 1982; Odiba \& Sanford, 1985). On the other hand, Kumar et al. (1991) evaluated levels of 0,30 and $60 \%$ of corn replacement by pearl millet in laying hen diets and reported no negative effects in egg production, feed intake, feed conversion and body weight. Furthermore, higher pearl millet inclusion levels increased egg weight.

Corn replacement by pearl millet in Leghorn laying hen diets during the second production cycle was evaluated by Collins et al. (1997), who formulated diets with the same levels of energy $(2,860 \mathrm{kcal} \mathrm{ME} / \mathrm{kg})$ and protein $(16 \% \mathrm{CP})$, and different levels of corn substitution $(0,50$ or $100 \%)$. Treatments had no effects on feed intake, egg production, egg weight and yolk weight, but pearl millet inclusion resulted in less pigmented eggs.

Café et al. (1999) assessed performance and egg quality of commercial laying hens fed diets with increasing substitution levels of metabolizable energy of pearl millet for corn. There were no statistical differences in egg production, feed intake, feed conversion, mean egg weight, and percentages of shell, yolk and albumen. On the other hand, yolk pigmentation evaluated using a Roche ${ }^{\circledR}$ color fan was poorer in eggs from laying hens fed pearl millet-based diets. Similarly to broiler chicken production, if consumers demand for more pigmented products, pearl millet-based diets for laying hens should be supplemented with carotene sources.

The evaluation of replacing conventional energy and protein sources with alternative sources in broiler chicken diets have shown that formulation based on digestible amino acids was more efficient than formulation based on total amino acids (Rostagno et al., 1995; Fernandez et al., 1995). The feed industry should consider this new alternative as another tool that can be used to reduce production costs without impairing animal performance. Nevertheless, contradictory results have been reported in commercial laying hens (Wangen, 1993; Silva et al., 2000; Casartelli, 2004).

This study evaluated performance, egg quality and production costs of eggs in commercial laying hens fed diets in which corn was replaced by pearl millet and formulated based on total or digestible amino acid requirements.

\section{MATERIAL AND METHODS}

Two hundred and forty Lohmann LSL 25 week-old laying hens were distributed in a completely randomized design using a $2 \times 5$ factorial (two amino acid recommendations $\times 5$ corn replacement levels) with 3 replicates of 8 birds per treatment. Recommendations for total amino acids and digestible amino acids were according to Rostagno et al. (2000). In both cases, the minimum requirements for lysine, sulfur amino acids, threonine, tryptophan and arginine were fulfilled. Replacement levels of corn by pearl millet were 0, 25, 50, 75 and $100 \%$.

Experimental diets had the same energy $(2,850 \mathrm{kcal}$ $\mathrm{ME} / \mathrm{kg})$, calcium (3.5\% Ca) and phosphorous $(0.45 \%$ available $\mathrm{P}$ ) levels. Amino acid and protein levels varied according to the criteria of total and digestible amino acid requirements, as shown in Table 1 and Table 2 .

Since it is widely known that yolk pigmentation is poorer due to pearl millet inclusion in diets for laying hens, an artificial pigment (Carophyl) was added to the experimental diets to result in xanthophyll levels similar to those of corn-based diets.

Performance and egg quality were evaluated during five periods of 21 days. At the end of each cycle, 
Filardi RS, Junqueira OM, Casartelli EM, Laurentiz AC, Duarte KF, Assuena V
Pearl Millet Utilization in Commercial Laying Hen Diets Formulated on a Total or Digestible Amino Acid Basis feed intake, egg production, egg weight and feed conversion $(\mathrm{kg} / \mathrm{kg}$ ) were evaluated. Egg quality was evaluated during the last three days of each cycle using Haugh Unit, yolk pigmentation index, egg specific gravity, and shell percentage and thickness. Yolk pigmentation index was obtained comparing the yolk color on a white surface with a color fan $\left(\right.$ Roche $\left.^{\circledR}\right)$.

The costs of the experimental diets were determined considering the composition and ingredient prices in December 2004. For statistical analysis, means of diet costs were done in function of the level milleto and according to amino acid recommendation. Estimates of production costs included only diet costs since other costs were similar for all treatments. Diet costs to produce one dozen eggs or one kilogram of eggs were calculated considering the amount of feed consumed to produce one dozen eggs or one kilogram of eggs and the price of diet per kilogram.

Performance and egg quality data were submitted to analysis of variance using the general linear model?
(SAS Institute, 2002). Polynomial regression was performed if there were significant effects $(p<0.05)$ of pearl millet inclusion levels.

\section{RESULTS AND DISCUSSION}

Table 3 presents performance means throughout the experimental period. There was a significant interaction $(p<0.01)$ between amino acid recommendations and levels of substitution of pearl millet for corn on feed intake, and simple effects are shown in Table 4. At pearl millet inclusion levels of 25,50 and $75 \%$, higher feed intake $(p<0.05)$ was seen in birds fed diets formulated based on total amino acid compared to digestible amino acid basis. However, when pearl millet was not added $(0 \%)$ or when corn was completely replaced by pearl millet $(100 \%)$, there were no effects $(p>0.05)$ of amino acid recommendations on feed intake. Within total amino acid recommendations, there was a linear decrease

\begin{tabular}{|c|c|c|c|c|c|}
\hline \multirow[t]{2}{*}{ Ingredients (\%) } & \multicolumn{5}{|c|}{ Pearl millet substitution for corn (\%) } \\
\hline & $0 \%$ & $25 \%$ & $50 \%$ & $75 \%$ & $100 \%$ \\
\hline Corn & 69.000 & 51.750 & 34.500 & 17.250 & 0.000 \\
\hline Soybean meal & 18.878 & 17.531 & 13.326 & 12.290 & 9.256 \\
\hline Pearl millet & 0.000 & 17.250 & 34.500 & 51.750 & 69.000 \\
\hline Corn gluten meal (60\% CP) & 0.000 & 0.000 & 2.336 & 1.951 & 3.241 \\
\hline Starch & 0.000 & 1.267 & 1.593 & 2.626 & 3.499 \\
\hline Limestone & 8.552 & 8.441 & 8.467 & 8.452 & 8.462 \\
\hline Dicalcium phosphate & 1.351 & 1.365 & 1.388 & 1.402 & 1.422 \\
\hline Kaolin & 0.590 & 0.000 & 0.559 & 0.000 & 0.000 \\
\hline Soybean oil & 0.526 & 1.255 & 2.107 & 3.017 & 3.790 \\
\hline Mineral + vitamin premix ${ }^{1}$ & 0.500 & 0.500 & 0.500 & 0.500 & 0.500 \\
\hline Sodium chloride & 0.430 & 0.436 & 0.447 & 0.453 & 0.461 \\
\hline DL-methionine - 98\% & 0.123 & 0.125 & 0.104 & 0.111 & 0.102 \\
\hline L-lysine - 78\% & 0.030 & 0.056 & 0.153 & 0.173 & 0.242 \\
\hline $\mathrm{BHT}$ & 0.020 & 0.020 & 0.020 & 0.020 & 0.020 \\
\hline Pigment & 0.000 & 0.004 & 0.000 & 0.005 & 0.005 \\
\hline Price (R\$/ton) & 399.7 & 405.0 & 395.8 & 404.5 & 404.7 \\
\hline \multicolumn{6}{|l|}{ Calculated levels (\%) } \\
\hline Metabolizable Energy (Mcal/kg) & 2,800 & 2,800 & 2,800 & 2,800 & 2,800 \\
\hline Crude protein (\%) & 14.50 & 14.51 & 14.50 & 14.50 & 14.50 \\
\hline Calcium (\%) & 3.65 & 3.65 & 3.65 & 3.65 & 3.65 \\
\hline Available Phosphorus (\%) & 0.34 & 0.34 & 0.34 & 0.34 & 0.34 \\
\hline Total arginine (\%) & 0.905 & 0.874 & 0.793 & 0.765 & 0.702 \\
\hline Digestible arginine. (\%) & 0.844 & 0.818 & 0.747 & 0.724 & 0.670 \\
\hline Total lysine (\%) & 0.721 & 0.721 & 0.721 & 0.721 & 0.721 \\
\hline Digestible lysine. (\%) & 0.641 & 0.647 & 0.657 & 0.663 & 0.671 \\
\hline Total methionine (\%) & 0.362 & 0.370 & 0.372 & 0.382 & 0.387 \\
\hline Digestible methionine (\%) & 0.340 & 0.348 & 0.350 & 0.361 & 0.366 \\
\hline Total Met+Cys (\%) & 0.617 & 0.617 & 0.617 & 0.617 & 0.617 \\
\hline Digestible Met+Cys (\%) & 0.556 & 0.557 & 0.558 & 0.560 & 0.561 \\
\hline Total threonine $(\%)$ & 0.564 & 0.562 & 0.559 & 0.555 & 0.551 \\
\hline Digestible threonine (\%) & 0.485 & 0.484 & 0.486 & 0.485 & 0.484 \\
\hline Total tryptophan (\%) & 0.164 & 0.169 & 0.163 & 0.168 & 0.166 \\
\hline Digestible tryptophan (\%) & 0.147 & 0.153 & 0.148 & 0.154 & 0.153 \\
\hline Xantophyll (mg/kg) & 15.180 & 15.385 & 15.400 & 15.233 & 15.695 \\
\hline
\end{tabular}

1 * - Levels per kg of diet: Vit. A - 8,000 IU; Vit. D3 - 2,000 IU; Vit. E - 50 mg; Vit. K3 - 3 mg; Vit. B1 - 1.5 mg; Vit. B2 - 4 mg; Vit. B6 - 0.12 mg, Vit. B12 - 15 mcg; Folacin - 0.6 mg; Pantothenic acid 10 mg; Niacin - 30 mg; Biotin - 0.1 mg; Choline - 300 mg; Iron - 50 mg; Copper - 10 mg; Zinc - 70 mg; Manganese - 100 mg; lodine - 1 mg; Selenium - 0.3 mg; Antioxidant 50 mg. 
Filardi RS, Junqueira OM, Casartelli EM, Laurentiz AC, Duarte KF, Assuena V

Pearl Millet Utilization in Commercial Laying Hen Diets Formulated on a Total or Digestible Amino Acid Basis

\begin{tabular}{|c|c|c|c|c|c|}
\hline \multirow[t]{2}{*}{ Ingredients (\%) } & \multicolumn{5}{|c|}{ Pearl millet substitution for corn (\%) } \\
\hline & $0 \%$ & $25 \%$ & $50 \%$ & $75 \%$ & $100 \%$ \\
\hline Corn & 69.000 & 51.750 & 34.500 & 17.250 & 0.000 \\
\hline Soybean meal & 15.351 & 13.600 & 11.773 & 9.966 & 9.106 \\
\hline Pearl millet & 0.000 & 17.250 & 34.500 & 51.750 & 69.000 \\
\hline Corn gluten meal ( $60 \%$ CP) & 0.000 & 0.294 & 0.652 & 1.000 & 0.563 \\
\hline Starch & 0.000 & 2.092 & 4.118 & 6.215 & 6.134 \\
\hline Limestone & 8.438 & 8.442 & 8.447 & 8.451 & 8.451 \\
\hline Dicalcium phosphate & 1.387 & 1.403 & 1.418 & 1.434 & 1.446 \\
\hline Kaolin & 1.436 & 1.802 & 2.188 & 2.546 & 3.890 \\
\hline Soybean oil & 3.099 & 2.045 & 1.048 & 0.000 & 0.000 \\
\hline Mineral + vitamin premix ${ }^{1}$ & 0.500 & 0.500 & 0.500 & 0.500 & 0.500 \\
\hline Sodium chloride & 0.436 & 0.443 & 0.450 & 0.457 & 0.463 \\
\hline DL-methionine - 98\% & 0.167 & 0.165 & 0.163 & 0.160 & 0.165 \\
\hline L-lysine - 78\% & 0.144 & 0.172 & 0.201 & 0.230 & 0.237 \\
\hline BHT & 0.020 & 0.020 & 0.020 & 0.020 & 0.020 \\
\hline Pigment & 0.000 & 0.003 & 0.006 & 0.008 & 0.014 \\
\hline L-arginine - 98\% & 0.000 & 0.000 & 0.000 & 0.000 & 0.005 \\
\hline L-tryptophan - 98\% & 0.022 & 0.019 & 0.016 & 0.013 & 0.006 \\
\hline Price $(R \$ /$ ton) & 430.8 & 432.5 & 434.3 & 433.7 & 434.1 \\
\hline \multicolumn{6}{|l|}{ Calculated levels (\%) } \\
\hline Metabolizable Energy (Mcal/kg) & 2,800 & 2,800 & 2,800 & 2,800 & 2,800 \\
\hline Crude protein (\%) & 12.90 & 12.90 & 12.90 & 12.90 & 12.90 \\
\hline Calcium (\%) & 3.65 & 3.65 & 3.65 & 3.65 & 3.65 \\
\hline Available Phosphorus (\%) & 0.34 & 0.34 & 0.34 & 0.34 & 0.34 \\
\hline Total arginine (\%) & 0.787 & 0.748 & 0.708 & 0.680 & 0.660 \\
\hline Digestible arginine (\%) & 0.732 & 0.700 & 0.666 & 0.642 & 0.620 \\
\hline Total lysine (\%) & 0.712 & 0.705 & 0.699 & 0.692 & 0.686 \\
\hline Digestible lysine (\%) & 0.640 & 0.640 & 0.640 & 0.640 & 0.640 \\
\hline Total methionine (\%) & 0.383 & 0.389 & 0.395 & 0.402 & 0.410 \\
\hline Digestible methionine (\%) & 0.362 & 0.368 & 0.375 & 0.3811 & 0.390 \\
\hline Total Met+Cys (\%) & 0.616 & 0.615 & 0.613 & 0.612 & 0.611 \\
\hline Digestible Met+Cys (\%) & 0.560 & 0.560 & 0.560 & 0.560 & 0.560 \\
\hline Total threonine (\%) & 0.501 & 0.498 & 0.496 & 0.493 & 0.492 \\
\hline Digestible threonine (\%) & 0.430 & 0.430 & 0.430 & 0.430 & 0.430 \\
\hline Total tryptophan (\%) & 0.163 & 0.163 & 0.163 & 0.163 & 0.163 \\
\hline Digestible tryptophan (\%) & 0.147 & 0.148 & 0.149 & 0.150 & 0.150 \\
\hline Xantophyll (mg/kg) & 15.180 & 15.385 & 15.450 & 15.450 & 15.695 \\
\hline
\end{tabular}

$(p<0.01)$ in feed intake with increasing levels of replacement of corn by pearl millet $(Y=86.7153$ $0.07038 X, R^{2}=0.89$ ). On the other hand, within digestible amino acid recommendations, there was a quadratic effect on feed intake $(Y=94.259-0.3196 \mathrm{X}$ $+0.00249 X^{2}, R^{2}=0.85$ ). Feed intake reduced until a replacement level of $64.18 \%$, and increased afterwards.

Café et al. (1999) evaluated levels of substitution of pearl millet for corn in laying hen diets and observed different patterns of feed intake during the experimental period. During the first period there was quadratic effect on feed intake and during the second period there was a linear decrease with increasing levels of pearl millet.

Amino acid recommendations had no effects ( $p>0.05)$ on any performance parameters evaluated in this study, but pearl millet levels affected $(p<0.01)$ egg weight and egg production (Table 3 ). There was a linear decrease in egg production $(Y=85.7153$ $\left.0.07038 X, R^{2}=0.89\right)$ and in egg weight $(Y=59.4950$ $\left.-0.02609 X, R^{2}=0.85\right)$ with increasing levels of substitution of pearl millet for corn. Café et al. (1999) did not report decrease in egg production due to the increase in corn substitution by pearl millet, but there was a linear decrease in egg weight during the first experimental period.

Egg quality means are shown in Table 5. There were no effects $(p>0.05)$ of amino acid recommendations or substitution of pearl millet for corn on Haugh unit, eggshell thickness and egg specific gravity. On the other hand, there was a significant interaction between the evaluated factors $(p<0.01)$ on yolk pigmentation index.

The simple effect means for amino acid recommendations and levels of pearl millet on yolk 
Filardi RS, Junqueira OM, Casartelli EM, Laurentiz AC, Duarte KF, Assuena V
Pearl Millet Utilization in Commercial Laying Hen Diets Formulated on a Total or Digestible Amino Acid Basis

Table 3 - Performance of laying hens fed diets formulated on a total or digestible amino acid basis and with increasing levels of pearl millet (25 to 45 weeks).

\begin{tabular}{|c|c|c|c|c|}
\hline 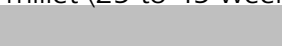 & Feed intake (g/day) & Egg production (\%) & Feed conversion $(\mathrm{kg} / \mathrm{kg})$ & Egg weight (g) \\
\hline \multicolumn{5}{|c|}{ Amino acid recommendation (AR) } \\
\hline Total & 91.32 & 84.37 & 1.845 & 58.53 \\
\hline Digestible & 87.95 & 82.01 & 1.876 & 57.58 \\
\hline \multicolumn{5}{|c|}{ Pearl millet substitution for corn (PM) } \\
\hline $0 \%$ & 94.86 & 87.56 & 1.820 & 59.65 \\
\hline $25 \%$ & 92.28 & 84.34 & 1.856 & 59.10 \\
\hline $50 \%$ & 87.74 & 81.61 & 1.880 & 57.72 \\
\hline $75 \%$ & 86.69 & 82.42 & 1.845 & 57.12 \\
\hline $100 \%$ & 86.61 & 79.72 & 1.901 & 57.37 \\
\hline \multicolumn{5}{|l|}{ F Values ${ }^{1}$} \\
\hline$A R$ & $15.70 * *$ & $4.29 \mathrm{~ns}$ & $0.01 \mathrm{~ns}$ & $2.60 \mathrm{~ns}$ \\
\hline PM & $15.34 * *$ & $4.95 * * 2$ & $1.48 \mathrm{~ns}$ & $5.66 * * 3$ \\
\hline$A R \times P M$ & $5.30 * *$ & $2.05 \mathrm{~ns}$ & $1.55 \mathrm{~ns}$ & $1.39 \mathrm{~ns}$ \\
\hline C.V (\%) & 3.93 & 3.03 & 1.97 & \\
\hline
\end{tabular}

$1 * *-p<0.01, *-p<0.05, n s=$ non significant (p>0.05). 2 - gg production $-Y=86.7153-0.07038 X ; R^{2}=0.89 ; p<0.01 .3$ Egg weight $-Y=59.4950$ $-0.02609 X ; R^{2}=0.85 ; p<0.01$

Table 4 - Simple effects of the significant interaction between amino acid recommendations and substitution of pearl millet for corn on feed intake.

\begin{tabular}{|c|c|c|c|c|c|}
\hline \multirow[t]{2}{*}{ Amino acid recommendation } & \multicolumn{5}{|c|}{ Pearl millet substitution for corn $(\%)$} \\
\hline & $0 \%$ & $25 \%$ & $50 \%$ & $75 \%$ & $100 \%$ \\
\hline Total ${ }^{1}$ & $95.33 \mathrm{a}$ & $96.30 \mathrm{a}$ & 89.79 a & $90.00 \mathrm{a}$ & $85.21 \mathrm{a}$ \\
\hline Digestible $^{2}$ & $94.40 \mathrm{a}$ & $88.26 \mathrm{~b}$ & $85.70 \mathrm{~b}$ & $83.38 \mathrm{~b}$ & $88.01 \mathrm{a}$ \\
\hline
\end{tabular}

Means followed by different letters in the columns are different by Tukey's Test $(\mathrm{p}<0.50) .1$ - Feed intake - total amino acids - $Y=96.0813-$ $0.10616 X ; R^{2}=0.73 ; p<0.01 .2$ - Feed intake - digestible amino acids $-Y=94.2590-0.31960 X+0.00249 X^{2} ; R^{2}=0.96 ; p<0.01$.

pigmentation are shown in Table 6. There were differences between amino acid recommendations within each level of substitution of pearl millet for corn. Lower yolk pigmentation index was seen at digestible amino acid recommendation only when $50 \%$ of corn was replaced with pearl millet. Increasing replacement levels resulted in a linear decrease in yolk pigmentation index both for total $\left(Y=9.828-0.0141 X ; R^{2}=0.90\right)$ and digestible $\left(Y=9.894-0.0176 X ; R^{2}=0.98\right)$ amino acid recommendations. Such effect on yolk pigmentation index corroborates previous findings reported by Café et al (1999), who also described a linear reduction in yolk pigmentation index with the increase in pearl millet levels.

Results of yolk pigmentation index indicated that variations in yolk color were observed even with artificial pigment supplementation. This suggests that although similar levels of xanthophylls were used in experimental diets, it was not possible to avoid poor pigmentation caused by pearl millet utilization. Nevertheless, effects on yolk color probably would have been even greater if no pigment had been supplemented to the diet, especially in the treatments with higher pearl millet inclusions, as previously reported by Café et al. (1999).

Eggshell percentage was affected by the levels of replacement of corn by pearl millet $(p<0.05)$, according to a quadratic equation $(Y=9.5542+0.0102 X$ $\left.+0.0001 X^{2}, R^{2}=0.85\right)$ whose derivative showed a maximum corn substitution by pearl millet of $51 \%$. Café et al. (1999) also reported a quadratic effect of pearl millet inclusion levels on eggshell percentage.

In our study, diet formulation on digestible amino acid basis resulted in decreased feed intake when pearl millet replaced 25,50 and $75 \%$ of corn. There was also reduction in yolk pigmentation index at levels higher than $50 \%$, but no effects on performance or internal and external traits of egg quality. In trials comparing total and digestible amino acid recommendations in diets containing alternative ingredients, Casartelli (2004) reported that in general diets formulated on digestible amino acid basis negatively affected bird performance, although there were no effects on egg quality parameters.

In the present study, formulation of laying hen diets on a digestible amino acid basis showed no benefits in some ways, results that disagree with previous findings reported by Wangen (1993). Although the requirements for lysine, sulfur amino acids, threonine, tryptophan and arginine have been fulfilled in diets based on digestible amino acid requirements and lower protein levels, a deficiency in non-essential amino acids might have occurred and essential amino acids might have been used to synthesize non-essential amino acids, as suggested by Keshavarz \& Jackson (1992). 


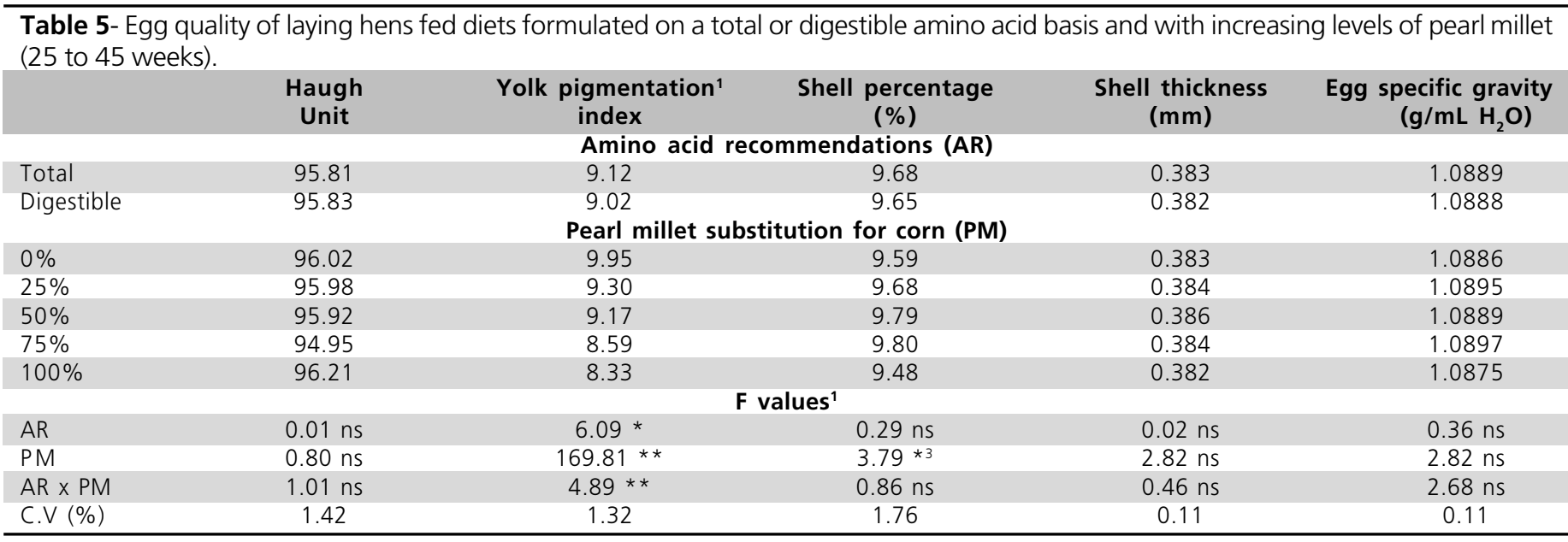

1 - Pigmentation index according to yolk color fan $\left(\right.$ Roche $\left.^{\oplus}\right) .2^{* *}-p<0.01,{ }^{*}=p<0.05$, ns $=$ not significant $\left.p>0.05\right) .3-Y=9.5542+0.0102 . X$ $+0.0001 . X^{2}, R^{2}=0.5$.

Table 6 - Simple effects of the significant interaction between amino acid recommendations and substitution of pearl millet for corn on yolk pigmentation index.

\begin{tabular}{cccccc} 
Amino acid recommendation & \multicolumn{5}{c}{ Pearl millet substitution for corn (\%) } \\
\cline { 2 - 6 } & $\mathbf{0 \%}$ & $\mathbf{2 5 \%}$ & $\mathbf{5 0 \%}$ & $\mathbf{7 5 \%}$ & $\mathbf{1 0 0 \%}$ \\
Total $^{1}$ & $9.92 \mathrm{a}$ & $9.22 \mathrm{a}$ & $9.37 \mathrm{a}$ & $8.68 \mathrm{a}$ & $8.43 \mathrm{a}$ \\
Digestible $^{2}$ & $9.98 \mathrm{a}$ & $9.39 \mathrm{a}$ & $8.98 \mathrm{~b}$ & $8.50 \mathrm{a}$ & $8.23 \mathrm{a}$ \\
\hline
\end{tabular}

Means followed by different letters in the columns are different by Tukey's Test $(p<0.50) .1-Y=9.828-0.0141 . X ; R^{2}=0.90(p<0.01) .2-Y=9.894$ $-0.0176 . X ; R^{2}=0.98(p<0.05)$.

Silva et al. (2000) also reported no significant improvement in production efficiency or egg quality when commercial laying hens were fed diets based on digestible amino acid requirements. According to these authors, the different digestibility of amino acids might have been responsible for the negative answers of laying hens fed diets formulated based on digestible amino acid requirements, since digestibility values presented in tables of chemical composition of feedstuffs have been reported in trials carried out with cecectomized roosters.

In relation to corn replacement by pearl millet, results indicated that bird performance decreased linearly with the increase in pearl millet levels, affecting feed intake, egg production and egg weight. Considering diet formulation based on digestible amino acids, feed intake decreased until the inclusion level of $64.18 \%$ and increased at higher levels. Egg quality was also affected; yolk pigmentation index decreased with the increase in pearl millet levels, but replacement levels up to $51 \%$ did not affect eggshell percentage. In terms of reduction in yolk coloration, it should be pointed out that due to the low content of xanthophylls in pearl millet, diets must be supplemented with natural or artificial pigments to assure acceptable yolk pigmentation indexes.
Economic parameters are presented in Table 7. They should help during decision-taking concerning diet formulation, considering digestible or total amino acid requirements and inclusion levels of pearl millet in commercial laying hen diets. Formulation based on total amino acids resulted in lower egg production costs in comparison to formulation based on digestible amino acids, both for egg mass $(\mathrm{kg})$ and dozen of produced eggs. The difference between total and digestible amino acid basis in the production costs of an egg box (30 dozens) was $R \$ 0.90$ (ninety cents). The higher cost of diets balanced according to digestible amino acid is due to the high costs of synthetic amino acids.

Pearl millet levels had no significant effects ( $p>0.05)$ on production costs per egg mass $(\mathrm{kg})$ or per dozen eggs. Despite the lower price of pearl millet ( $R \$ 0.22$ / $\mathrm{kg})$ in relation to corn $(\mathrm{R} \$ 0.30 / \mathrm{kg})$, diet costs were not lower when corn was replaced by pearl millet. It may be seen in Table 1 and Table 2 that corn replacement by pearl millet requires increased levels of soybean oil, corn gluten, starch and L-lysine. The costs for increasing the levels of these ingredients in pearl millet-based diets counterbalanced the lower costs of pearl millet. 


\begin{tabular}{|c|c|c|c|}
\hline \multirow{2}{*}{\multicolumn{4}{|c|}{$\begin{array}{c}\text { Cost of diet (R\$/ton) } \\
\text { Amino acid recommendation (AR) }\end{array}$}} \\
\hline & & & \\
\hline Total & 0.4091 & $0.75 \mathrm{~b}$ & $0.53 \mathrm{~b}$ \\
\hline Digestible & 0.4331 & $0.80 \mathrm{a}$ & $0.56 a$ \\
\hline \multicolumn{4}{|c|}{ Pearl millet substitution for corn (PM) } \\
\hline $0 \%$ & 0.4152 & 0.76 & 0.54 \\
\hline $25 \%$ & 0.4187 & 0.78 & 0.55 \\
\hline $50 \%$ & 0.4151 & 0.77 & 0.54 \\
\hline $75 \%$ & 0.4191 & 0.77 & 0.53 \\
\hline $100 \%$ & 0.4194 & 0.80 & 0.55 \\
\hline \multicolumn{4}{|c|}{ F values ${ }^{1}$} \\
\hline$A R$ & - & $42.16^{* *}$ & $30.98 * *$ \\
\hline PM & - & $2.09 \mathrm{~ns}$ & $1.55 \mathrm{~ns}$ \\
\hline$A R \times P M$ & - & $2.08 \mathrm{~ns}$ & $2.67 \mathrm{~ns}$ \\
\hline C.V (\%) & - & 3.20 & 3.14 \\
\hline
\end{tabular}

Means followed by different letters in the columns are different by Tukey's Test $(p<0.50)$.

\section{CONCLUSIONS}

Digestible amino acid recommendations resulted in decreased feed intake and increased production costs per egg mass $(\mathrm{kg})$ or dozen eggs in relation to total amino acid recommendations.

There was a linear reduction in feed intake, egg production, egg weight and yolk pigmentation index with increasing inclusion levels of pearl millet, i.e., increasing levels of corn replacement by pearl millet affected bird performance negatively. The increase of pearl millet inclusion until $51 \%$ only improved eggshell percentage.

Increasing pearl millet levels did not result in lower production costs, but pearl millet utilization should be more viable in regions where it is less expensive than corn.

\section{REFERENCES}

Andrews DJ, Kumar KA. Pearl millet for food, feed, and forage. Advanced Agronomy 1992; 48:89-139.

Café MB, Stringhini JH, Mogyca NS, França AFS, Rocha FRT.Milhetogrão (Pennisetum glaucum (L.)R.Br) como substituto do milho em rações para poedeiras comerciais. Arquivos Brasileiros de Medicina Veterinária e Zootecnia 1999; 51:171-176.

Casarteli EM. Alimentos alternativos ao milho e farelo de soja em rações de poedeiras comerciais formuladas com base em aminoácidos totais e digestíveis. [Dissertação]. Jaboticabal (SP): Universidade Estadual Paulista; 2004.

Collins VP, Cantor AH, Pescatore AJ, Straw MI, Ford MJ. Pearl millet in layer diets enhances egg yolk n-3 fatty acids. Poultry Science 1997; 76:326-330.
Davis AJ, Dale NM, Ferreira FJ. Pearl millets as an alternative feed ingredient in broiler diets. Journal Applied Poultry Research 2003; 12:137-144.

Fernandez S R, Zhang $Y$, Parsons CM. Dietary formulation with cottonsed meal on a total amino acid versus a digestible amino acid basis. Poultry Science 1995; 74:1168-1179.

Keshavarz K, Jackson ME. Performance of growing pullets and laying hens fed low-protein, amino acid supplemented diets. Poultry Science 1992; 71:905-918.

Kumar AM, Reddy VR, Reddy PV, Reddy RS. Utilization of pear millet (Pennisetum typhoides) for egg production. British Poultry Science 1991; 23:463-469.

Luis ES, Sullivan TW, Nelson LA. Nutritional values of proso millet in layer diets. Poultry Science 1982; 61:1176-1182.

Odiba JY, Sanford PE. A comparison of the performance of caged layers when fed sorghum grain and millet. Poultry Science 1985; 54(S1):155.

Rostagno HS, Albino LTF, Donzele JL, Gomes PC, Ferreira AS, Oliveira RF, Lopes CD. Tabelas brasileiras para aves e suínos (Composição de alimentos e exigências nutricionais de aves e suínos). Viçosa (MG):UFV, Imprensa Universitária; 2000. 141 p.

Rostagno HS, Pupa JMR, Pack M. Diet formulation for broilers based on total versus digestible amino acid. Journal Applied Poultry Research 1995; 4:293-299.

SAS Institute. SAS (Statistical Analysis System). User's guide statistics. Cary, NC:SAS Institute Inc; 2002.

Silva JHV, Mukami F, Albino LFT. Uso de rações à base de aminoácidos digestíveis para poedeiras. Revista Brasileira de Zootecnia 2000; 29(1):1446-1451.

Wangen X. A study of diet formulation for layers on available amino acid basis. Acta Veterinary and Zootechiny Sinica 1993; 24(4):319-325. 